\title{
The effectiveness of short-term microwave irradiation on the process of seed extraction from Scots pine cones (Pinus sylvestris L.)
}

\author{
Monika Aniszewska, \\ Witold Zychowicz, \\ Arkadiusz Gendek
}

\begin{abstract}
The influence of short-term microwave irradiation on the process of seed extraction from Scots pine cones was investigated in this study. Cones from the Brzesko Forest District (near Kraków, southern Poland) were collected in 2015. The size and changes in the mass of cones during the process of seed extraction, as well as the relations between these parameters, were analyzed. Changes in water content and drying rate of cones were modeled using suitable mathematical equations. The thermal balance of the whole process of seeds extraction was calculated, and the heat necessary to extract the seeds was determined. Cones were initially exposed to $2.45 \mathrm{GHz}$ microwaves with a power of $800 \mathrm{~W}$ for either 5 or 15 seconds. Subsequently, cones were placed in a circulating air oven and seeds extracted under convective drying at a constant temperature of $50 \pm 0.1{ }^{\circ} \mathrm{C}$. We found that seeds from cones subjected to 15 -seconds microwave radiation were dramatically damaged, while no significant difference were found in germination and quality of seeds between cones subjected to the 5 -seconds microwave pre-treatment and control cones, both yielding first-class quality seeds (mean germination capacity $>90 \%$ ). The results of this study could help developing microwave-dryer control algorithms to support the automated process of cone seed extraction in large-capacity extraction plants.
\end{abstract}

Keywords: Seed Extraction Heat, Drying Process, Moisture Content, Seed Viability

\section{Introduction}

The literature on seed extraction from conifer cones reports processes conducted under laboratory and/or industrial conditions, both in extraction chambers and cabinets. All stages of the process of production of forest reproductive material, from cones collection to nursery cultivation and selection, may have an effect on its genetic diversity - mainly by directional selection that should be carefully considered (Ivetic et al. 2016). Most studies have sought to identify methods of convective cone drying

$\square$ Institute of Mechanical Engineering, Department of Biosystem Engineering, Warsaw University of Life Sciences - SGGW, Nowoursynowska 164, 02-787 Warsaw (Poland)

@ Monika Aniszewska

(monika_aniszewska@sggw.pl)

Received: Mar 07, 2019 - Accepted: Dec 05, 2019

Citation: Aniszewska M, Zychowicz W, Gendek A (2020). The effectiveness of shortterm microwave irradiation on the process of seed extraction from Scots pine cones (Pinus sylvestris L.). iForest 13: 73-79. - doi: 10.3832/ifor3089-012 [online 2020-02-13]

Communicated by: Giacomo Goli characterized by short processing time and high viability of the resulting seeds (Bogdanow 1966, Antosiewicz 1979, Nelson 1985, Aniszewska 2007). To date, research was carried out on changes in moisture content of cones during seed extraction, the determinants of those changes, as well as moisture content upon seed release (Aniszewska 2007). Despite these efforts, the introduction of new methods for seed extraction has not led to shortening the process, nor to avoiding non-simultaneous opening of cones in the drying chamber. Furthermore, there is little evidence in the literature on the use of additional treatments, such as brief exposure of individual cones to microwaves. It is worth to remember that excessive microwave irradiation of biological material results in tissue and cell damage (Davis et al. 1973, Krajewski 1990a, 1990b, Kraszewski \& Nelson 2004, Warchalewski et al. 2007, Jakubowski 2010a, 2010b, Pietruszewski \& Kania 2011, Slowinski 2013, Friesen et al. 2014, Sahin 2014). The available evidences on intermittent microwave drying indicate that it affects the biophysical characteristics of various plants (Diprose et al. 1984), including rice (Xu et al. 2017), amaranth (Hernández Maqueda et al. 2019), rapeseed (Lupinska et al. 2009, Isaev et al. 2016, Ren et al. 2018), and tree seeds and seedlings (Pattanaik et al. 2015), which lose vitality due to an abrupt microwave-induced temperature rise.
The effects of microwave irradiation on Pinus sylvestris cones were described by Aniszewska \& Slowinski (2016), who determined safe cone exposure time in terms of ensuring seed quality. Furthermore, Aniszewska (2016) investigated surface temperature changes in cones exposed to microwaves for different periods. Finally, Hemis et al. (2015), who analysed microwave-assisted drying of rapeseed, soy, and corn, reported that microwaves may cause seed cracking, which is deleterious to their quality.

The objective of the paper was to elucidate changes in the moisture content of pine cones briefly exposed to microwave irradiation prior to conventional seed extraction, taking into account the effects of cone size, initial moisture content, and drying temperature. Additional goals were to develop a mathematical model describing the drying process and assess the viability of the obtained seeds. The eventual increase of the effectiveness of the process of seed extraction from cones will support research efforts aimed at increasing the production of pine cones (Moreno-Fernández et al. 2013).

\section{Materials and methods}

\section{Characteristics of the material}

Scots pine (Pinus sylvestris L.) cones were collected in December 2015 from the So60 seed stand $\left(53^{\circ} 00^{\prime} \mathrm{N}, 15^{\circ} 00^{\prime} \mathrm{E}\right)$ in the 
Brzesko Forest District (Kraków State Forests Regional Directorate). The cones were stored under refrigeration at $0{ }^{\circ} \mathrm{C}$ for 8 months. Following removal from refrigeration, the cones were acclimatized at room temperature $\left(20-22{ }^{\circ} \mathrm{C}\right)$ for approximately 2 $h$ at a relative air humidity of $40 \%$.

Prior to seed extraction, the length (I) and the widest diameter $(d)$ of each cone were measured. The diameter was determined in two orthogonal directions and the mean calculated. The measurements were made using a 0-150 $\mathrm{mm}$ digital hard ened stainless steel caliper with an LCD dis play, with an accuracy of $0.1 \mathrm{~mm}$.

\section{Microwave irradiation and seed extraction}

The pine cones were divided into three lots, each containing 40 specimens (a total of 120). The control lot ("lot C") was subjected to conventional seed extraction, while the other two lots were initially exposed to $2.45 \mathrm{GHz}$ microwaves with a power of $800 \mathrm{~W}$ in a Sharp R-200 ${ }^{\circledast}$ laboratory microwave oven (Vestel Poland Sp. z o.o., Warsaw, Poland). The exposure time was either 5 seconds ("lot $5 \mathrm{~s}$ ") or $15 \mathrm{sec}$ onds ("lot $15 \mathrm{~s}$ ").

Temperature distribution within the microwave oven was determined in order to appropriately position the cones. A container measuring $12 \times 8 \mathrm{~cm}$ divided into 24 cells $(6 \times 4)$ was placed in the oven, with 10 $\mathrm{mL}$ of demineralized water at $21{ }^{\circ} \mathrm{C}$ in each cell. The container with water was exposed to the maximum microwave power for 60 and $120 \mathrm{~s}$, and then photographed with a VIGOcam $\mathrm{V}_{50}{ }^{\oplus}$ thermographic camera (VIGO System S.A., Ozarów Mazowiecki, Poland) from a distance of $50 \mathrm{~cm}$. The adopted emissivity coefficient for water was 0.97. Images were acquired at a resolution of $384 \times 288$ pixels and processed using Therm v.2.29.3 software (VIGO System). Temperature was recorded with an accuracy of $0.1{ }^{\circ} \mathrm{C}$. The obtained temperature distribution is shown in Fig. 1.

After determining temperature distribution in the oven, cones were individually irradiated. Each cone was placed horizontally in the middle of a rotating glass plate. Before and 10 min after microwave treatment each cone was weighed on a WPS210 $\mathrm{S}^{\circledast}$ laboratory balance (Radwag, Radom,
Poland) to record their initial $\left(m_{p}\right)$ and final $\left(m_{k}\right)$ weight with an accuracy of $0.001 \mathrm{~g}$. It was experimentally determined that cone weight did not further change 10 min after the end of thermal treatment. Subsequently, the pine cones were placed in a Heraeus UT $6120^{\circ}$ circulating air oven (Kendro Laboratory Products $\mathrm{GmbH}$, Hanau, Germany) and subjected to seed extraction under convective drying at a constant temperature of $50 \pm 0.1^{\circ} \mathrm{C}$ and relative air humidity decreasing from $42 \%$ to $12 \%$. The convective drying lasted 10 hours. Temperature and humidity in the oven and in the laboratory were monitored using an FTH $100^{\circledR}$ sensor (Geo FENNEL, Kassel, Germany) with an accuracy of $0.01{ }^{\circ} \mathrm{C}$ and $0.01 \%$, respectively.

During seed extraction, cones were placed on the grill inside the oven. The decrease in weight was recorded every $60 \pm 1$ min over $10 \mathrm{~h}$.

\section{Seed extraction process and seed extraction heat}

The study sought to describe the seed extraction process by mathematical equations, including the effects of initial microwave irradiation. Two equations were developed: one for the time interval of o$0.16(6) \mathrm{h}$ and another one for 0.16(6)-10 $\mathrm{h}$. The former equation represents a linear function corresponding to the period required for the microwave treatment $(5 \mathrm{~s}$ or $15 \mathrm{~s}$ ) of individual cones comprising a given experimental lot, so that the entire lot could be then simultaneously placed in the convective (circulating air) oven. The latter equation is an exponential function corresponding to the time of seed extraction in the convective oven.

Given that the moisture content of the studied pine cones was much lower than that of so far researched plants or plant products, changes in cone moisture content $\left(u_{i}\right)$ during seed extraction in the convective oven were modeled using the exponential equation for the second period of drying solids given by Pabis (1982 - eqn. 1):

$$
u_{i}=\left(u_{o}-u_{k}\right) \cdot \exp (-b \cdot \tau)+u_{k}
$$

where $u_{0}$ is the initial cone moisture content, $u_{k}$ is the final cone moisture content, $b$ is the characteristic drying coefficient, $\tau$ is the drying time, exp is the base of the natural logarithm. Moreover, instantaneous cone weight $\left(\mathrm{m}_{\mathrm{i}}\right)$ was measured during seed extraction to calculate instantaneous cone moisture content $\left(u_{w}\right)$ as the ratio of the weight of water $\left(m_{\mathrm{H} 2 \mathrm{O}}\right)$ to the dry weight of the cone $\left(m_{s}\right)$, which was also measured.

The coefficient $b$ was determined for each cone on the basis of actual changes in moisture content (eqn. 2 ):

$$
b=\sum_{i=1}^{n} \frac{\ln \frac{u_{i}-u_{k}}{u_{o}-u_{k}}}{\tau_{i}}
$$

where $n$ is the number of readings of cone weight $m_{i}$ and time $\tau_{i}$ during seed extraction. This coefficient was averaged and adopted as the characteristic parameter of the mathematical model describing moisture content changes in the cones, with the other characteristic parameters of the model being $u_{o}$ and $u_{k}$.

The drying rate (loss of cone moisture over time) was calculated as the derivative of moisture content duration $u_{i}$ (eqn. 3 ):

$$
\frac{d u_{i}}{d \tau}=-b \cdot\left(u_{o}-u_{k}\right) \cdot \exp (-b \cdot \tau)
$$

The pine cones were weighed using a WP$\mathrm{S}_{210 \mathrm{~S}^{\circledast}}$ laboratory scale (Radwag, Radom, Poland) with an accuracy of $0.001 \mathrm{~g}$. The dry weight of cones was determined after seed extraction by drying at $105 \pm 1{ }^{\circ} \mathrm{C}$ until constant weight. After drying, the number of scales on the cone and the number of obtained seeds were counted. The seeds were cleaned and dewinged. The overall weight of seeds and wings from a given cone was measured with an accuracy of $0.001 \mathrm{~g}$.

The heat of extraction $Q$ for individual cones was calculated from the formula (eqn. 4):

$$
Q=Q_{1}+Q_{2}
$$

where $Q_{1}$ is the amount of heat supplied to the cone to reach the drying temperature (eqn. 5), and $Q_{2}$ is the amount of heat needed to evaporate the water during seed extraction (eqn. 6):

$$
Q_{1}=Q_{w}+Q_{s}=m_{w} \cdot c_{w} \cdot \Delta t+m_{s} \cdot c_{s} \cdot \Delta t
$$
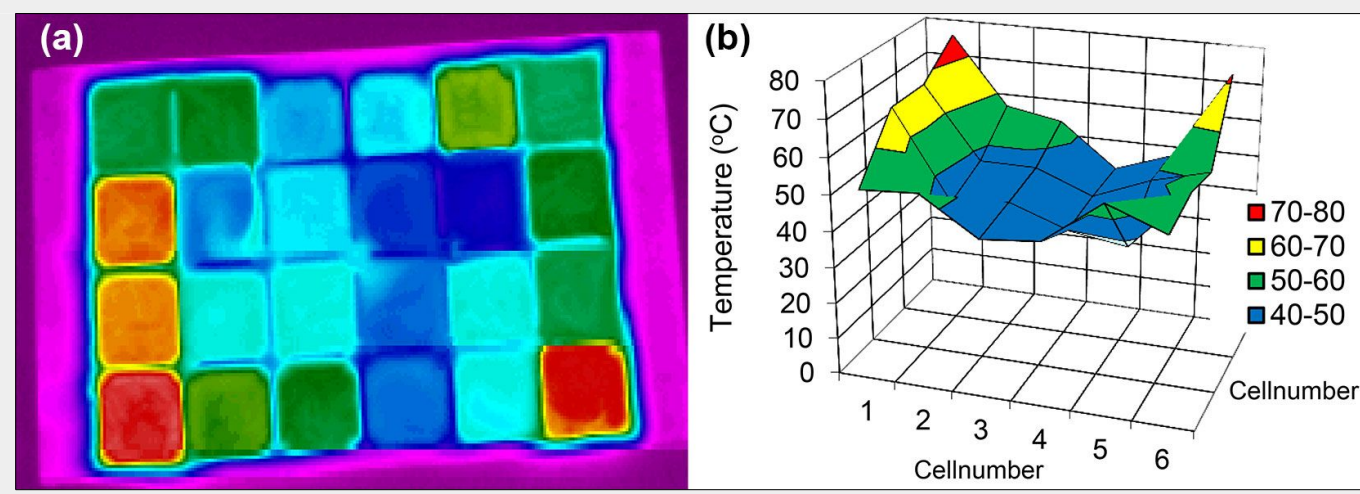

Fig. 1 - Temperature distribution in a container filled with water exposed to microwaves in the oven after 1 min. (a): thermograph; (b): 3D-graph. 


$$
Q_{2}=\left(m_{w}-m_{w k}\right) \cdot c_{p}
$$

(6)

$Q_{s}$ is the amount of heat needed to heat up the cone $(J), Q_{w}$ is the amount of heat needed to heat up water $(J), c_{p}$ is the heat of water evaporation equal to $2354.54 \mathrm{~J} \mathrm{~g}^{-1}$, $c_{s}$ is the specific heat of the cone, equal to $1.356 \mathrm{~J}\left(\mathrm{~g}^{\circ} \mathrm{C}\right)^{-1}, \mathrm{C}_{\mathrm{w}}$ is the specific heat of water equal to $4.18868 \mathrm{~J}\left(\mathrm{~g}{ }^{\circ} \mathrm{C}\right)^{-1}, \mathrm{~m}_{\mathrm{w}}$ is the weight of water $(\mathrm{g}), m_{\mathrm{wk}}$ is the weight of water remaining in the cone $(\mathrm{g}), \Delta t$ is the temperature difference $\left({ }^{\circ} \mathrm{C}\right)$.

The amount of water that evaporated from the cone $\left(m_{w e}, g\right)$ and the amount of water remaining in the cone $\left(m_{w f}, g\right)$ were calculated as follows (eqn. 7, eqn. 8):

$$
\begin{aligned}
& m_{w e}=m_{p}-m_{k} \\
& m_{w f}=m_{w}-m_{w e}
\end{aligned}
$$

where $m_{p}$ is initial mass of the cone in grams, $m_{k}$ is the final weight of the cone in grams.

In calculating seed extraction heat, the heat needed to heat up the oven and air was not taken into account. Thus, $Q$ is the effective seed extraction heat.

\section{Germination energy and capacity}

To determine whether the adopted seed extraction conditions result in viable seeds, their germination energy and capacity were assessed (PN-R-65700 1998, Zaleski et al. 2006). The pine seeds were placed on filter paper in a Jacobsen germinator (Laborset, Lódz, Poland) in three replicates of 100 specimens for each seed lot $(5 \mathrm{~s}, 15 \mathrm{~s}$, and $\mathrm{C}$ ), totaling nine replicates (i.e., 900 specimens). The twenty-four hour operating cycle of the germinator consisted of 8 hours of lighting and 16 hours of dark. During the lighting period the seed temperature was kept at $30^{\circ} \mathrm{C}$, while during the remaining 16 hours it was equal to $20^{\circ} \mathrm{C}$. Temperature settings were regulated by the TERMO-STAB RBS1 ${ }^{\oplus}$ controller (TERMOSTAB, Warsawa, Poland) with an accuracy of $\pm 1{ }^{\circ} \mathrm{C}$. GRASSLIN Talento ${ }^{\oplus} 371$ exposure time controller (Grässlin $\mathrm{GmbH}$, St. Georgen, Germany) was used. The light source consisted of two fluorescent lamps TUNGSRAM 36W-F74 DAYLIGHT. Germination energy was measured after 14 days and germination capacity after 28 days of experiment. Based on those results, the seed quality class was determined according to the standard PN-R-65700 (1998). First class pine seeds should germinate in $91 \%$ of the cases.

\section{Statistical analysis}

The external parameters of the cones were statistically evaluated using the software Statistica ver. 13 (Dell 2016). The Shapiro-Wilk test was applied to evaluate normal distribution of the dependent variables. Differences in mean size and weight parameters were assessed by the ANOVA F-test and Duncan test for equal sample sizes. Homogeneity of variances were also tested using the Levene's test. All analyses were made at a statistical significance level of 0.05 .

\section{Results}

\section{Characteristic parameters of Scots pine} cones

Tab. 1 presents the basic size parameters (length, diameter, and length-to-diameter ratio) and initial weight for the three studied lots of pine cones. The mean length, diameter, and initial weight calculated for all cones were $45.77 \mathrm{~mm}, 21.50 \mathrm{~mm}$, and 7.98 $\mathrm{g}$, respectively, which is within the typical range for Scots pine (Bialobok et al. 1993). Cone size and weight showed a normal distribution after the Shapiro-Wilk test. Duncan test for equal sample sizes did not show any significant differences in length, diameter, or initial weight between the three studied lots of cones, which means that they may be compared each other.

The mean length-to-diameter ratio was 2.13, which places the cones in the longand-thick category $(1 / d=0.20-0.25)$ according to Pravdin (1964). In the studied material, there were also 16 egg-shaped cones $(I / d=1.50-2.00)$ and 2 long ones $(I / d=2.50$ 3.00).

A significant linear relationship $(R=0.630)$ was found between cone diameter $(d)$ and length ( $I$ - eqn. 9):

$d=0.254 \cdot l+9.865$

(9)

and between initial weight $\left(m_{p}\right)$ and length of cones $(R=0.554-$ eqn. 10$)$ :

$$
m_{p}=0.021 \cdot l+1.142
$$

Thus, the longer the cone, the larger its diameter and initial weight. The mean initial moisture content of the cones $\left(u_{0}\right)$ amounted to $23 \pm 1.5 \%$.

Tab. 1 - Cone size and weight statistics for the three investigated lots. Two lots were initially exposed to $2.45 \mathrm{GHz}$ microwaves, the exposure time was either $5 \mathrm{~s}$ ("lot $5 \mathrm{~s}$ ")

\begin{tabular}{|c|c|c|c|c|c|c|c|c|c|}
\hline Lot & Param & Mean & Min & Max & Range & Variance & SD & CV & SE \\
\hline \multirow[t]{4}{*}{$5 \mathrm{~s}$} & $l$ & 45.84 & 35.70 & 52.50 & 16.80 & 25.64 & 5.06 & 11.05 & 0.90 \\
\hline & $d$ & 21.55 & 17.00 & 24.60 & 7.60 & 3.56 & 1.89 & 8.75 & 0.33 \\
\hline & $l / d$ & 2.13 & 1.69 & 2.55 & 0.86 & 0.04 & 0.19 & 8.98 & 0.03 \\
\hline & $m_{\mathrm{p}}$ & 7.96 & 4.79 & 11.32 & 6.53 & 3.36 & 1.83 & 23.01 & 0.32 \\
\hline \multirow[t]{4}{*}{$15 \mathrm{~s}$} & 1 & 45.83 & 37.80 & 56.80 & 19.00 & 18.66 & 4.32 & 9.43 & 0.76 \\
\hline & $d$ & 21.28 & 18.40 & 25.00 & 6.60 & 3.29 & 1.81 & 8.52 & 0.32 \\
\hline & $l / d$ & 2.16 & 1.89 & 2.62 & 0.72 & 0.03 & 0.16 & 7.55 & 0.03 \\
\hline & $m_{\mathrm{p}}$ & 7.97 & 5.30 & 13.15 & 7.85 & 3.83 & 1.96 & 24.55 & 0.35 \\
\hline \multirow[t]{4}{*}{ C } & $l$ & 45.24 & 37.60 & 56.10 & 18.50 & 19.92 & 4.46 & 9.87 & 0.80 \\
\hline & $d$ & 21.67 & 17.80 & 26.10 & 8.30 & 4.12 & 2.03 & 9.36 & 0.36 \\
\hline & $l / d$ & 2.09 & 1.73 & 2.50 & 0.77 & 0.03 & 0.18 & 8.61 & 0.03 \\
\hline & $m_{\mathrm{p}}$ & 8.01 & 5.10 & 12.68 & 7.58 & 3.90 & 1.98 & 24.11 & 0.35 \\
\hline
\end{tabular}
or $15 \mathrm{~s}$ ("lot $15 \mathrm{~s}$ "). The control lot ("lot (") was subjected only to conventional seed extraction. $(I)$ : length $(\mathrm{mm}) ;(d)$ : diameter $(\mathrm{mm}) ;(I / d)$ : length-to-diameter ratio; $\left(\mathrm{m}_{\mathrm{p}}\right)$ : initial weight (g).
The process of seed extraction

The total seed extraction time for Scots pine cones lasted $10 \mathrm{~h}$, which was sufficient for all cones to open and release seeds. Moisture content for the studied lots is given in Tab. 2. Statistical analysis revealed that the mean moisture content values did not differ significantly between the three lots of cones, whereby the results can be deemed homogeneous. Throughout the 10 $\mathrm{h}$ long drying process, the cones initially exposed to microwaves for $5 \mathrm{~s}$ lost $1.13 \mathrm{~g}$ (from $0.670 \mathrm{~g}$ to $1.780 \mathrm{~g}$ ), while those with a $15 \mathrm{~s}$ initial exposure lost $1.14 \mathrm{~g}$ (from 0.821 $\mathrm{g}$ to $1.839 \mathrm{~g}$ ). A $5 \mathrm{~s}$ exposure to microwaves led to an average decrease in cone weight of $0.036 \pm 0.014 \mathrm{~g}$ (from $0.010 \mathrm{~g}$ to 0.060 g), while a $15 \mathrm{~s}$ exposure led to a decrease of $0.447 \pm 0.127 \mathrm{~g}$ (from $0.230 \mathrm{~g}$ to $0.841 \mathrm{~g}$ ). Changes in moisture content calculated from weight loss indicate that microwave heating resulted in a moisture loss of 0.0055 (0.5\%) and 0.069 (6.9\%) $\mathrm{kg}_{\mathrm{H} 2 \mathrm{O}} \mathrm{kg}_{\mathrm{dw}}{ }^{-1}$ for the $5 \mathrm{~s}$ and $15 \mathrm{~s}$ lots, respectively.

In the case of control cones, moisture content $u_{p}$ equaled $u_{o}$ as they were not pretreated with microwave irradiation prior to

Moisture content $u_{0}$, final moisture content $u_{k}$, and $b$ coefficients characteristic of the drying curve significantly differed between cones initially exposed to microwaves for $5 \mathrm{~s}$ and $15 \mathrm{~s}$, while no significant differences were found between the $5 \mathrm{~s} \mathrm{lot}$ and the control lot, as evaluated by the Duncan test (Tab. 3).

After $10 \mathrm{~h}$ of seed extraction, the lowest final moisture content was found for the cones pretreated with microwaves for $15 \mathrm{~s}$ (0.050 $\mathrm{kg}_{\mathrm{H}_{2} \mathrm{O}} \mathrm{kg}_{\mathrm{dw}^{-1}}$, or $\left.5.0 \%\right)$. In turn, the lowest $b$ coefficient was identified for the cones pretreated with microwaves for $15 \mathrm{~s}$ $\left(0.311 \mathrm{~h}^{-1}\right)$.

Fig. 2a presents the moisture content change in the course of seed extraction for two cones exposed to microwaves for $5 \mathrm{~s}$ placement in the convective oven. 
Tab. 2 - Parameters of the mathematical equation describing seed extraction from Scots pine cones. $\left(u_{\mathrm{p}}\right)$ : moisture content prior to microwave irradiation $\left(\mathrm{kg}_{\mathrm{H}_{2} \mathrm{O}} \mathrm{kg}_{\mathrm{dw}}{ }^{-1}\right)$; $\left(u_{0}\right)$ : moisture content after microwave irradiation $\left(\mathrm{kg}_{\mathrm{H}_{2} \mathrm{O}} \mathrm{kg}_{\mathrm{dw}}{ }^{-1}\right) ;\left(u_{\mathrm{k}}\right)$ : final moisture content after seed extraction $\left(\mathrm{kg}_{\mathrm{H}_{2} \mathrm{O}} \mathrm{kg}_{\mathrm{dw}}{ }^{-1}\right)$; (b): coefficient $\left(1 \mathrm{~h}^{-1}\right)$ from eqn. 1 to 3 (see text). (SD): standard deviation; (CV): coefficient of variation; (SE): standard error of the mean.

\begin{tabular}{lllllllll}
\hline Lot & Param & Mean & Min & Max & Range & SD & CV & SE \\
\hline $5 \mathrm{~s}$ & $u_{\mathrm{p}}$ & 0.232 & 0.205 & 0.269 & 0.064 & 0.015 & 6.425 & 0.003 \\
& $u_{\mathrm{o}}$ & 0.227 & 0.199 & 0.263 & 0.064 & 0.015 & 6.575 & 0.003 \\
& $u_{\mathrm{k}}$ & 0.057 & 0.029 & 0.087 & 0.058 & 0.009 & 16.285 & 0.002 \\
& $\mathrm{~b}$ & 0.31 & 0.14 & 0.44 & 0.30 & 0.07 & 21.57 & 0.01 \\
\hline $15 \mathrm{~s}$ & $u_{\mathrm{p}}$ & 0.227 & 0.189 & 0.264 & 0.075 & 0.015 & 6.688 & 0.003 \\
& $u_{\mathrm{o}}$ & 0.157 & 0.120 & 0.206 & 0.086 & 0.018 & 11.731 & 0.003 \\
& $u_{\mathrm{k}}$ & 0.050 & 0.020 & 0.076 & 0.056 & 0.011 & 21.868 & 0.002 \\
& $\mathrm{~b}$ & 0.39 & 0.29 & 0.47 & 0.18 & 0.04 & 11.14 & 0.01 \\
\hline $\mathrm{C}$ & $u_{\mathrm{p}}=u_{0}$ & 0.233 & 0.205 & 0.267 & 0.062 & 0.013 & 5.587 & 0.002 \\
& $u_{\mathrm{k}}$ & 0.058 & 0.046 & 0.077 & 0.031 & 0.008 & 13.740 & 0.001 \\
& $\mathrm{~b}$ & 0.32 & 0.21 & 0.40 & 0.24 & 0.07 & 21.97 & 0.01 \\
\hline
\end{tabular}

or $15 \mathrm{~s}$ prior to extraction (curves E.5 and E.15, respectively). Mathematical equations describe those curves according to eqn. 1 and eqn. 3. The process of seed extraction following $5 \mathrm{~s}$ exposure to microwaves is given by eqn. 11 , for $u_{0}=0.217 \mathrm{~kg}_{\mathrm{H} 2 \mathrm{O}} \mathrm{kg}_{\mathrm{dw}}{ }^{-1}, u_{\mathrm{k}}$ $=0.052 \mathrm{~kg}_{\mathrm{H}_{2} \mathrm{O}} \mathrm{kg}_{\mathrm{dw}^{-1}}$, and $b=0.361 \mathrm{~h}^{-1}$ (eqn. 11):

$$
u_{i}(\tau)=0.165 \cdot \exp (-0.36 \cdot \tau)+0.052
$$

for $\tau \in(0.16(6)-10>$.

The extraction process following $15 \mathrm{~s}$ exposure to microwaves is given by eqn. 12 ,

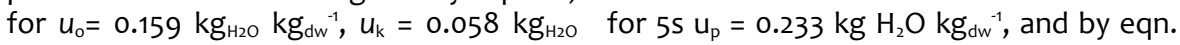

Fig. 2 - Changes in moisture content (a) and drying rates (b) for cones subjected to seed extrac tion with $5 \mathrm{~s}$ and 15 s microwave pretreatment.

(a): Moisture content changes described by linear ( $\mathrm{L})$ and exponential ( $E$ ) functions; (b): drying rate (S: seed extraction).

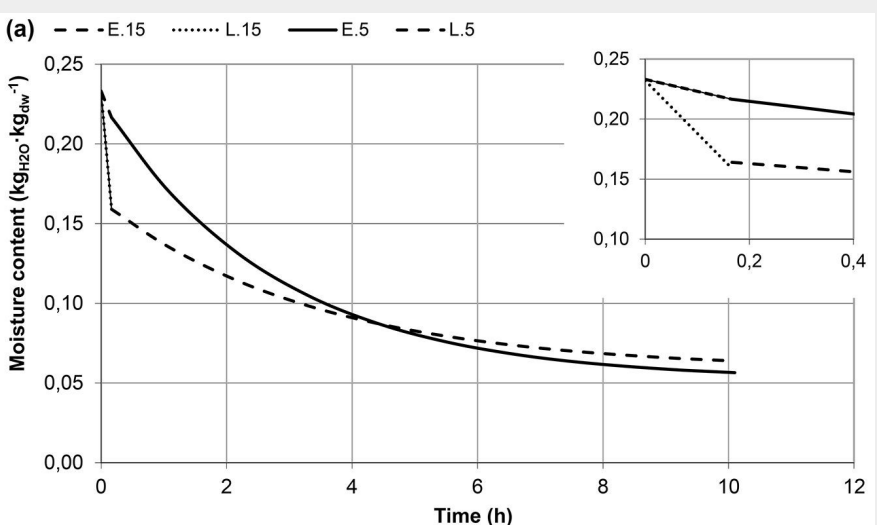

(b) $---\mathrm{s} .15-\mathrm{s} .5$

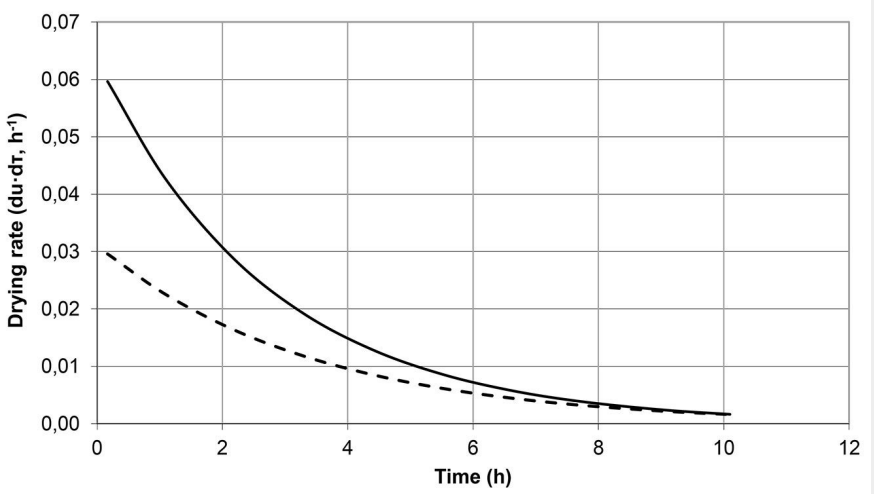

$$
u_{i}(\tau)=0.101 \cdot \exp (-0.29 \cdot \tau)+0.058
$$
$13[\tau \in<0-0.16(6)>]$ : $14[\tau \in<0-0.16(6)>]:$

$$
u_{i}(\tau)=0.233-0.439 \cdot \tau
$$

for $15 \mathrm{su}_{\mathrm{p}}=0.232 \mathrm{~kg} \mathrm{H}_{2} \mathrm{O} \mathrm{kg}_{\mathrm{dw}}{ }^{-1}$.

Fig. $2 b$ shows drying rate curves for the studied cones, expressed by eqn. 15 for the $5 \mathrm{~s} \operatorname{lot}[\tau \in<0-0.16(6)>]$ :

$$
\frac{d u_{i}}{d \tau}=0.059 \exp (-0.29 \cdot \tau)
$$

and eqn. 16 for the $15 s \operatorname{lot}[\tau \in<0-0.16(6)>]$ :

$$
\frac{d u_{i}}{d \tau}=0.029 \cdot \exp (-0.29 \cdot \tau)
$$

\section{Seed extraction heat}

The obtained thermal balance shows that the amount of heat supplied to the control cones dried in a convective oven ranged from $257.46 \mathrm{~J}$ to $642.98 \mathrm{~J}$, with the heat needed to evaporate water being 1669.37$4428.89 \mathrm{~J}$ (Tab. 4). The heat needed to increase cone temperature $\left(Q_{1}\right)$ was calculated to be 271.97-640.25 J and 740.51$1849.79 \mathrm{~J}$ for cones initially exposed to $\mathrm{mi}-$

$$
\text { for } \tau \in(0.16(6)-10>\text {. }
$$

Fig. 2a also shows an initial loss of moisture caused by exposure to microwaves for $5 \mathrm{~S}$ and $15 \mathrm{~S}$ (functions L. 5 and L.15, respectively). The pretreatment, which lasted for a total of $10 \mathrm{~min}$, is described by linear eqn.

$$
u_{i}(\tau)=0.233-0.099 \cdot \tau
$$
crowaves for $5 \mathrm{~S}$ and $15 \mathrm{~S}$, respectively. In turn, the mean amount of heat necessary to evaporate water $\left(\mathrm{Q}_{2}\right)$ was $84.76 \mathrm{~J}$ and $1052.57 \mathrm{~J}$ for cones exposed to microwaves for $5 \mathrm{~s}$ and $15 \mathrm{~s}$, respectively. The total heat needed for seed extraction, as computed from eqn. 4, was 2163.79-5068.08 J for lot $5 \mathrm{~s}$ and 3007.05-6750.64 J for lot $15 \mathrm{~s}$.

Weight, number, and quality of extracted seeds

Descriptive statistics for the weight and number of seeds extracted from pine cones are reported in Tab. 5. Seed weight accounted on average for $2 \%$ of the initial weight of cones. A significant correlation was found between the weight of the extracted seeds and cone length and initial weight ( $R=0.385$ and $R=0.539$, respectively).

The results of the seed quality evaluation are presented in Tab. 6. It is worth noting that a $5 \mathrm{~s}$ exposure to microwaves did not significantly affect the quality of pine seeds

Tab. 3 - Results ( $p$-values) of the Duncan test for differences in cone moisture content after microwave irradiation $\left(u_{0}\right)$, final moisture content $\left(u_{k}\right)$, and $b$ coefficient for the three studied lots. $\left.{ }^{*}\right)$ : $p<0.05$; (ns): not significant.

\begin{tabular}{ccccc}
\hline Lot & Param & $5 \mathrm{~s}$ & $15 \mathrm{~s}$ & $\mathrm{C}$ \\
\hline \multirow{4}{*}{$5 \mathrm{~s}$} & $u_{\mathrm{o}}$ & - & $0.0001^{*}$ & $0.1114^{\mathrm{ns}}$ \\
& $u_{\mathrm{k}}$ & - & $0.0043^{*}$ & $0.4021^{\mathrm{ns}}$ \\
& $b$ & - & $0.0001^{*}$ & $0.6098^{\mathrm{ns}}$ \\
\multirow{4}{*}{$15 \mathrm{~s}$} & $u_{\circ}$ & $0.0001^{*}$ & - & $0.0001^{*}$ \\
& $u_{\mathrm{k}}$ & $0.0043^{*}$ & - & $0.0300^{*}$ \\
& $b$ & $0.0001^{*}$ & - & $0.0001^{*}$ \\
& $u_{\mathrm{o}}$ & $0.1114^{\mathrm{ns}}$ & $0.0001^{*}$ & - \\
$\mathrm{C}$ & $u_{\mathrm{k}}$ & $0.4021^{\mathrm{ns}}$ & $0.0300^{*}$ & - \\
& $b$ & $0.6098^{\mathrm{ns}}$ & $0.0001^{*}$ & - \\
\hline
\end{tabular}


Tab. 4 - Seed extraction heat (expressed in J) for control cones (C) and cones exposed to microwave irradiation for $5 \mathrm{~s}$ (" 5 ") and $15 \mathrm{~s}$ ("15"). $\left(Q_{1}\right)$ : amount of heat supplied to the cone to reach the drying temperature; $\left(Q_{2}\right)$ : amount of heat needed for water evaporation during seed extraction; (Q): heat of extraction (sum of $Q_{1}$ and $Q_{2}$ ); (M): heat calculated for microwave exposure time; (PM): heat calculated for the seed extraction period after exposure to microwaves; (MPM): sum of seed extraction heat for both stages (microwaves irradiation and convection drying). (SD): standard deviation; (CV): coefficient of variation; (SE): standard error.

\begin{tabular}{|c|c|c|c|c|c|c|c|c|}
\hline Variable & Mean & Min & Max & Range & Variance & SD & CV & SE \\
\hline$Q_{1} C$ & 418.09 & 257.46 & 642.98 & 385.52 & 9992.8 & 99.96 & 23.91 & 17.95 \\
\hline $\mathrm{Q}_{2} \mathrm{C}$ & 2780.10 & 1669.37 & 4428.89 & 2759.52 & 458593.5 & 677.20 & 24.36 & 121.63 \\
\hline QC & 3198.20 & 1926.83 & 5070.73 & 3143.90 & 600941.1 & 775.20 & 24.24 & 139.23 \\
\hline$Q_{1} 5$ & 457.71 & 271.97 & 640.25 & 368.28 & 11311.0 & 106.35 & 23.24 & 18.80 \\
\hline$Q_{2} 5 \mathrm{M}$ & 84.76 & 23.55 & 155.40 & 131.85 & 1121.0 & 33.49 & 39.50 & 5.92 \\
\hline Q 5 M & 542.47 & 295.51 & 753.62 & 458.11 & 15386.0 & 124.04 & 22.87 & 21.93 \\
\hline $\mathrm{Q}_{1} 5 \mathrm{PM}$ & 407.86 & 243.64 & 571.02 & 327.38 & 9033.0 & 95.04 & 23.30 & 16.80 \\
\hline $\mathrm{Q}_{2} 5 \mathrm{PM}$ & 2566.11 & 1624.63 & 3830.84 & 2206.20 & 311131.0 & 557.79 & 21.74 & 98.60 \\
\hline Q 5 PM & 2973.97 & 1868.27 & 4382.83 & 2514.56 & 416670.0 & 645.50 & 21.71 & 114.11 \\
\hline Q 5 MPM & 3516.44 & 2163.79 & 5068.08 & 2904.29 & 580192.0 & 761.70 & 21.66 & 134.65 \\
\hline$Q_{1} 15 M$ & 1127.92 & 740.51 & 1849.79 & 1109.28 & 80562.0 & 283.83 & 25.16 & 50.18 \\
\hline $\mathrm{Q}_{2} 15 \mathrm{M}$ & 1052.57 & 541.54 & 1980.17 & 1438.62 & 88940.0 & 298.23 & 28.33 & 52.72 \\
\hline Q $15 M$ & 2180.49 & 1420.09 & 3829.96 & 2409.87 & 299574.0 & 547.33 & 25.10 & 96.76 \\
\hline$Q_{1} 15 P M$ & 355.15 & 232.22 & 570.85 & 338.64 & 8376.0 & 91.52 & 25.77 & 16.18 \\
\hline $\mathrm{Q}_{2} 15 \mathrm{PM}$ & 1641.72 & 894.73 & 2670.05 & 1775.32 & 196848.0 & 443.68 & 27.02 & 78.43 \\
\hline Q 15 PM & 1996.87 & 1151.80 & 3193.10 & 2041.31 & 281204.0 & 530.29 & 26.56 & 93.74 \\
\hline Q $15 M P M$ & 4177.36 & 3007.05 & 6750.64 & 3743.59 & 1024785.0 & 1012.32 & 24.23 & 178.95 \\
\hline
\end{tabular}

as compared to the controls, while $15 \mathrm{~s}$ of the scales to separate.

irradiation dramatically damaged $100 \%$ of the seeds (none germinated).

Analysis of variance revealed no statistical differences in the germination energy $(p=0.221$ and $F=1.862)$ and capacity $(p=$ 0.854 and $F=0.0368$ ) between seeds from control cones and those exposed to microwaves for $5 \mathrm{~s}$.

\section{Discussion}

The process of cones drying using microwave irradiation, which is part of the seed extraction process, was carried out in a typical manner. The decrease in humidity was similar to that observed by Orlowska (2018).

The microwave power applied in the present study led to strong seed damage after $15 \mathrm{~s}$, therefore a shorter exposure time is desirable. Further, a $5 \mathrm{~s}$ microwave treatment resulted in first class cones. The increased seed extraction heat in cones exposed to microwaves was associated with the fact that their temperature surged in the first extraction step. Aniszewska (2016) reported that cone temperature rose to 52 ${ }^{\circ} \mathrm{C}$ after $5 \mathrm{~s}$ of microwave irradiation and to almost $100{ }^{\circ} \mathrm{C}$ after $15 \mathrm{~s}$. Aniszewska \& Slowinski (2016) and Rukuni (1997) reported that cone exposure to $800 \mathrm{~W}$ microwave irradiation for up to $30 \mathrm{~s}$ did not compromise seed viability. The former authors irradiated cones placed one next to another on a tray, with the irradiation distributed across all cones. In contrast, in the present study, microwaves acted on individual cones placed in the middle of a rotating glass vessel, which means that they had a more focused effect. The treatment time was short, but in most cases sufficient for
Aladjadjiyan (2010), and Radzevičius et al. (2013) reported that the use of microwave irradiation with a correct selection of parameters can lead to an increase in germi-

nation capacity and energy. Microwaves irradiation has been found to accelerate seed extraction, but it should be examined whether the treated seeds are weaker and equally suitable for long-term storage (Za-

Tab. 5 - Seed weight (SW, g) and number of seeds per cone (N, pcs.) obtained from the three studied lots of pine cones. (SD): standard deviation; (CV): coefficient of variation; (SE): standard error of the mean.

\begin{tabular}{clcccccccc}
\hline Lot & Param & Mean & Min & Max & Range & Variation & SD & CV & SE \\
\hline $5 \mathrm{~s}$ & SW & 0.172 & 0.067 & 0.320 & 0.253 & 0.005 & 0.072 & 41.731 & 0.013 \\
& $\mathrm{~N}$ & 23 & 10 & 44 & 34 & 77 & 9 & 38 & 1.6 \\
\hline $15 \mathrm{~s}$ & $\mathrm{SW}$ & 0.156 & 0.050 & 0.342 & 0.292 & 0.004 & 0.064 & 41.271 & 0.011 \\
& $\mathrm{~N}$ & 20 & 4 & 37 & 30 & 54 & 7 & 36 & 1.3 \\
$\mathrm{C}$ & $\mathrm{SW}$ & 0.201 & 0.075 & 0.421 & 0.346 & 0.007 & 0.085 & 38.581 & 0.015 \\
& $\mathrm{~N}$ & 27 & 10 & 48 & 38 & 73 & 9 & 31 & 1.5 \\
\hline
\end{tabular}

Tab. 6 - Assessment of germination quality for seeds from the three studied lots. $\left(\mathrm{Ge}_{14 \mathrm{~d}}\right)$ : germination energy at 14 days (\%); $\left(\mathrm{GC}_{28 \mathrm{~d}}\right)$ : germination capacity at 28 days (\%); (Mean Gc): Mean germination capacity (\%).

\begin{tabular}{|c|c|c|c|c|c|c|}
\hline Lot & $\begin{array}{c}\text { Sample } \\
\text { no. }\end{array}$ & $\begin{array}{c}\mathrm{Ge}_{14 \mathrm{~d}} \\
(\%)\end{array}$ & $\begin{array}{l}\mathrm{Gc}_{28 \mathrm{~d}} \\
(\%)\end{array}$ & $\begin{array}{c}\text { Quality } \\
\text { class }\end{array}$ & $\begin{array}{c}\text { Mean Gc } \\
(\%)\end{array}$ & $\begin{array}{l}\text { Mean quality } \\
\text { class }\end{array}$ \\
\hline \multirow{4}{*}{$5 \mathrm{~s}$} & 1 & 86 & 90 & II & \multirow{4}{*}{93} & \multirow{4}{*}{ I } \\
\hline & 2 & 92 & 97 & I & & \\
\hline & 3 & 86 & 90 & II & & \\
\hline & 4 & 92 & 96 & I & & \\
\hline \multirow{4}{*}{$15 \mathrm{~s}$} & 1 & 0 & 0 & - & \multirow{4}{*}{0} & \multirow{4}{*}{ - } \\
\hline & 2 & 0 & 0 & - & & \\
\hline & 3 & 0 & 0 & - & & \\
\hline & 4 & 0 & 0 & - & & \\
\hline \multirow{4}{*}{ Control } & 1 & 91 & 93 & I & \multirow{4}{*}{94} & \multirow{4}{*}{ I } \\
\hline & 2 & 96 & 99 & I & & \\
\hline & 3 & 90 & 91 & 1 & & \\
\hline & 4 & 91 & 92 & I & & \\
\hline
\end{tabular}


leski et al. 2006). Based on our results, the germination capacity and energy of seeds from cones subjected to $5 \mathrm{~s}$ microwave irradiation did not differ significantly from those of seeds from control cones.

In this study, the microwave treatments affected seed extraction, lowered initial moisture content, and modified the drying curve, as proven by the comparison of $b$ coefficients. Nonetheless, these findings should be verified on a larger sample of cones of diverse origins and with different values of initial moisture content.

The process of seed extraction from Scots pine cones subjected to initial microwave irradiation may be described using a linear equation for moisture content changes induced by microwave heating, and using an exponential equation for those induced by convective heating. In the latter case, the characteristic values are the initial moisture content $u_{0}$, the final moisture content $u_{k}$, and the $b$ coefficient, which on average amounted to $0.227 \mathrm{~kg}_{\mathrm{H}_{2} \mathrm{O}}$ $\mathrm{kg}_{\mathrm{dw}^{-1}}{ }^{-1}, 0.057 \mathrm{~kg}_{\mathrm{H}_{2} \mathrm{O}} \mathrm{kg}_{\mathrm{dw}^{-1}}$, and $0.311 \mathrm{~h}^{-1}$, respectively, for cones which were initially subjected to a $5 \mathrm{~s}$ microwave pre-treatment.

The proposed mathematical description of seed extraction process with a preliminary microwave treatment followed by convective drying may be used to determine the course of cone opening and seed release.

The irradiation of cones with microwaves for $15 \mathrm{~s}$ decreased their moisture content by an average of $7 \%$. Due to the need to maintain seed viability, convection drying with temperature control should be used in the further drying process. The reduction of moisture content obtained through microwave irradiation reduces the next convection drying stage by about 2 hours at $35^{\circ} \mathrm{C}$ or by about 1 hour at $50{ }^{\circ} \mathrm{C}$. On average, the initial reduction of cones moisture content by $0.5 \%$ results in a reduction of convection drying time at $35^{\circ} \mathrm{C}$ by $8 \mathrm{~min}$ utes.

The application of microwave irradiation in the process of seed extraction from Scots pine cones may be beneficial, but requires further study involving cone exposure to lower microwave powers (less than the $800 \mathrm{~W}$ setting used in the present experiments) and different microwave frequencies.

\section{Conclusions}

The application of microwaves with a power of $800 \mathrm{~W}$ before seed extraction from Scots pine cones with a mean moisture content of $23 \%$ decreased cone moisture and caused some scales to separate.

Individual pine cones exposed to a microwave power of $800 \mathrm{~W}$ for $5 \mathrm{~s}$ yielded first-class seeds. However, our results suggest that further moisture decreases could be attained by extending the treatment duration at a lower power. At the studied microwave power, however, cone exposure must be shorter than $15 \mathrm{~s}$ to reduce the risk of seed damage. This finding should be confirmed in further laboratory studies.

The proposed mathematical descriptions of the process of cone drying using microwave radiation can be used (after further validation) in microwave dryer control algorithms.

The process involving a $5 \mathrm{~s}$ microwave pre-treatment followed by convective drying accelerated seed extraction from pine cones at low relative humidity as compared to convective drying alone. However, since the combined process required a greater energy input, a cost calculation should be performed to estimate its economic feasibility.

\section{Funding}

This research did not receive any specific grant from funding agencies in the public, commercial, or no-profit sectors.

\section{References}

Aladjadjiyan A (2010). Influence of stationary magnetic field on lentil seeds. International Agrophysics 24 (3): 321-324.

Aniszewska M (2007). Effectiveness of commercial Scots pine seed extraction at industrial scale. Sylwan 151: 22-28.

Aniszewska M (2016). The change in weight and surface temperature of a pine cone (Pinus sylvestris L.) as a result of microwave irradiation. Forest Research Papers 77: 56-67. - doi: 10.1515/frp-2016-0007

Aniszewska M, Slowinski K (2016). Effects of microwave irradiation by means of a horn antenna in the process of seed extraction on Scots pine (Pinus sylvestris L.) cone moisture content and seed germination energy and capacity. European Journal of Forest Research 135: 633-642. - doi: 10.1007/s10342-016-0960-0 Antosiewicz Z (1979). Wplyw temperatury i wilgotnosci powietrza na jakosć nasion sosny i swierka w czasie luszczenia szyszek [Influence of temperature and air humidity on the quality of pine and spruce seeds during seed extraction from cones]. Las Polski 6: 11-12. [in Polish] Bialobok S, Boratynski A, Bugala W (1993). Biologia sosny zwyczajnej [Biology of Scots pine]. Polska Akademia Nauk Instytut Dendrologii, Poznan-Kórnik, Poland, pp. 680. [in Polish]

Bogdanow B (1966). O suszkie szyszek w wakuomie [Drying cones in a vacuum]. Lesnoje Chozjajstwo 3: 57-60. [in Polish]

Davis FS, Wayland JR, Merkle MG (1973). Phytotoxicity of a UHF electromagnetic field. Nature 241 (5387): 291-292. - doi: 10.1038/241291ao Dell Inc. (2016). Dell Statistica (data analysis software system), version 13 . Web site. [online] URL: http://software.dell.com.pl

Diprose MF, Benson FA, Willis AJ (1984). The effect of externally applied electrostatic fields, microwave radiation and electric currents on plants and other organisms, with special reference to weed control. The Botanical Review 50: 171-223. - doi: 10.1007/BF02861092

Friesen AP, Conner RL, Robinson DE, Barton WR, Gillard CL (2014). Effect of microwave radiation on dry bean seed infected with Xanthomonas axonopodis pv. phaseoli with and without the use of chemical seed treatment. Crop Protec- tion 65: 77-85. - doi: 10.1016/j.cropro.2014.07.0 07

Hemis M, Choudhary R, Gariépy Y, Raghavan VGS (2015). Experiments and modelling of the microwave assisted convective drying of canola seeds. Biosystems Engineering 139: 121-127. doi: 10.1016/j.biosystemseng.2015.08.010

Hernández Maqueda R, Ballesteros Redondo I, Jiménez Jácome S, Moreno ÁH (2019). Microwave drying of amaranth and quinoa seeds: effects of the power density on the drying time, germination rate and seedling vigour. Journal of Microwave Power and Electromagnetic Energy 52 (4): 299-311. - doi: 10.1080/08327823.201 8.1534052

Isaev AV, Bastron AV, Yakhontova AS (2016). The research of unevenness degree influence of heating of colza seeds in emf uhf on their energy of germination and viability. Bulletin of KrasGAU 4: 131-137. [online] URL: http://agris. fao.org/agris-search/search.do?recordID=RU201 6002075

Ivetić V, Devetaković J, Nonić M, Stanković D, Nikolić M (2016). Genetic diversity and forest reproductive material - from seed source selection to planting. iForest - Biogeosciences and Forestry. 9: 801. - doi: 10.3832/ifor1577-009

Jakubowski T (2010a). Wplyw promieniowania mikrofalami sadzeniaków ziemniaka na plonowanie roslin [The effect of microwave irradiation of seed tubers on potato plant yield]. Biuletyn Instytutu Hodowli i Aklimatyzacji Roslin 257 (258): 177-183. [in Polish]

Jakubowski T (2010b). Wplyw terminu stymulacji mikrofalami sadzeniaków na wzrost i plonowanie roslin ziemniaka (Solanum tuberosum L.) [Effect of seed potatoes microwave stimulation on the growth and yields of potato (Solanum tuberosum L.)]. Acta Agrophysica 16 (2): 295-313. [in Polish]

Krajewski A (1990a). Mozliwosć zastosowania mikrofal do dezynsekcji iglastego drewna budowlanego [The possibility of using microwaves for disinfection of coniferous construction timber]. Wydawnictwa PKZ, Warszawa, Poland, pp. 70. [in Polish]

Krajewski A (1990b). Zwalczanie owadów szkodników technicznych drewna za pomoca mikrofal [Control of insects - technical pests of wood by means of microwaves]. Ochrona Zabytków 43 (1): 27-34. [in Polish]

Kraszewski AW, Nelson SO (2004). Microwave permittivity determination in agricultural products. Journal of Microwave Power and Electromagnetic Energy 39: 41-52. - doi: 10.1080/0832 7823.2004.11688507

Lupinska A, Koziol A, Araszkiewicz M, Lupinski M (2009). The changes of quality in rapeseeds during microwave drying. Drying Technology 27: 857-862. - doi: 10.1080/07373930903021717

Moreno-Fernández D, Cañellas I, Calama R, Gordo J, Sánchez-González M (2013). Thinning increases cone production of stone pine (Pinus pinea L.) stands in the Northern Plateau (Spain). Annals of Forest Science 70: 761-768. doi: 10.1007/s13595-013-0319-3

Nelson SO (1985). RF and microwave energy for potential agricultural applications. Journal of Microwave Power 20: 65-70. - doi: 10.1080/1607 0658.1985.11720292

Orlowska M (2018). Influence of microwaves ra- 
diation on pine cones (Pinus sylvestris L.) on the efficiency of the process and the quality of hulled seeds. Thesis, Warsaw University of Life Sciences - SGGW, Faculty of Production Engineering, Warsaw, Poland, pp. 47.

Pabis S (1982). Teoria konwekcyjnego suszenia produktów rolniczych [Theory of convection drying of agricultural products]. Panstwowe Wydawnictwo Rolnicze i Lesne, Warszawa, Poland, pp. 228. [in Polish]

Pattanaik S, Dash A, Mishra R, Nayak P, Mohanty $R$ (2015). Seed germination and seedling survival percentage of Shorea robusta Gaertn. $f$. in buffer areas of Similipal Biosphere Reserve, Odisha, India. Journal of Ecosystem and Ecography 4: 153. - doi: 10.4172/2157-7625.1000153

Pietruszewski S, Kania K (2011). Microwave effect on the germination kinetics of seeds of white lupine and consumptive pea. Acta Agrophysica 18: 121-129.

PN-R-65700 (1998). Material siewny. Nasiona drzew i krzewów lesnych i zadrzewieniowych [Polish Standard - Seed material. Seeds of forest trees and shrubs and woodland shrubs]. Polish Committee for Standardization, Warsaw,
Poland, pp. 33. [in Polish]

Pravdin LF (1964). Sosna obyknovennaja Izmencivost', vnutrividovaja sistematika i selecija [Scots pine, variability, systematics and improvement]. Akadenia Nauk ZSRR, Moskwa, Russia, pp. 191. [in Russian]

Radzevičius A, Sakalauskienë S, Dagys M, Simni A, Karklelienë $R$, Bobinas $C$, Duchovskis $P$ (2013). The effect of strong microwave electric field radiation on vegetable seed germination and seedling growth rate. Zemdirbyste-Agriculture 100 (2): 179-184. - doi: 10.1308o/z-a2013.100. 023

Ren X, Wang L, Xu B, Wei B, Liu Y, Zhou C, Ma H, Wang $Z$ (2018). Influence of microwave pretreatment on the flavor attributes and oxidative stability of cold-pressed rapeseed oil. Drying Technology 37 (3): 397-408. - doi: 10.1080/0 7373937.2018.1459682

Rukuni D (1997). Seed extraction methods and quality effects in Pinus radiata D. Don. Master of Applied Science Thesis, Massey University, Palmerston North, New Zealand. [online] URL: http://mro.massey.ac.nz/handle/10179/4209 Sahin H (2014). Effects of microwaves on the germination of weed seeds. Journal of Biosystems Engineering 39: 304-309. - doi: 10.5307/ JBE.2014.39.4.304

Slowinski K (2013). The influence of microwave radiation emitted to non-disinfected nursery soil on the survivability and chosen biometric characteristics of Scots pine (Pinus sylvestris L.). Zeszyty Naukowe Uniwersytetu Rolniczego Im H Kollataja w Krakowie 517 (394), pp. 122. Warchalewski JR, Dolinska R, Blaszczak W (2007). Microscope analysis of two generations of wheat grain crops grown from microwave heated seeds. Acta Agrophysica 10: 727-737.

Xu F, Chen Z, Huang M, Li C, Zhou W (2017). Effect of intermittent microwave drying on biophysical characteristics of rice. Journal of Food Process Engineering 40: e12590. - doi: 10.1111/jfp e.12590

Zaleski A, Anisko E, Kantorowicz W (2006). Zasady oceny nasion $w$ Lasach Panstwowych [Principles of seed evaluation in State Forests]. In: "Elementy genetyki i hodowli selekcyjnej drzew lesnych". Centrum Informacyjne Lasów Panstwowych, Warszawa, Poland, pp. 317-326. [in Polish] 